\title{
Prevalence of Human Immunodeficiency Virus Infection in Alcoholics
}

\author{
Luiz Carlos Marques de Oliveira ${ }^{+}$, Rômulo Gustavo Pereira, \\ Ureliano Cintra Reis
}

\begin{abstract}
Departamento de Clínica Médica, Universidade Federal de Uberlândia, Avenida Pará 1720, Campus Umuarama, 38400-902 Uberlândia, MG, Brasil
\end{abstract}

To verify the prevalence of infection by human immunodeficiency virus (HIV) in alcoholics we studied 131 alcoholic patients (119 males and 12 females) with a mean age of $44.3 \pm 10.8$ years. Serum samples were collected from this group and analysed, by ELISA, for antibodies against HIV as well as for serological markers for hepatitis $B$ virus $(H B V)$ and hepatitis $C$ virus $(H C V)$. As we have previously described, we found a high prevalence of $H B V(26.4 \%)$ and $H C V(4.2 \%)$ markers as compared to the prevalence of these markers in samples of normal blood donors from Uberlândia's Hemocentro Regional, which are $4 \%$ and $0.4 \%$, respectively. Of the 131 patients, four (3\%) had antibodies against HIV, three (75\%) of which were injecting drug users (IDU). In the HIV-negative group, only one patient was an $I D U$. The prevalence of HIV in our population, according to data from the city's Health Secretary, varies from $3.1 \%$ to $6.2 \%$. We conclude that, at least for the moment, alcoholism per se, did not constitute an important risk factor for HIV infection. However, acquired immunodeficiency syndrome is a rather recent disease as compared to hepatitis $B$ and $C$ and, as the transmission routes are similar for HIV and hepatitis viruses, an increase in the incidence of HIV infection in alcoholics may be just a question of time.

Key words: human immunodeficiency virus - alcoholism - hepatitis B virus - hepatitis C virus

In a recent work (Oliveira et al. 1999) we determined that alcoholics that came for treatment at the Alcohol Outpatient Center of our hospital had a high prevalence of serological markers of hepatitis $B$ virus (HBV) and hepatitis $\mathrm{C}$ virus (HCV), as reported for other regions as well (Naito et al. 1977, Basile et al. 1981, Hislop et al. 1981, Bréchot et al. 1982, Caldwell et al. 1991, Halimi et al. 1991, Laskus et al. 1992, Befrits et al. 1995, González Quintela et al. 1995). Transmission routes of human immunodeficiency virus (HIV) are similar to those of these hepatitis viruses, especially HBV. Also, the use of alcoholic beverages prior to sex predisposes individuals for unsafe sexual behaviors, i.e., without protection against HIV infection (Fitterling et al. 1993, Shillington et al. 1995). Moreover, for heterosexual alcoholics, there is an association between a higher alcohol dependence and a higher risk for HIV infection (Boscarino et al. 1995).

Therefore, the present study aims at assessing the prevalence of infection by the HIV among alcoholics seeking treatment at our service.

\footnotetext{
${ }^{+}$Corresponding author. Fax: +55-34-218.2349. E-mail: oliveiralcm@ufu.br

Received 27 March 2000

Accepted 19 June 2000
}

\section{PATIENTS AND METHODS}

We studied 131 patients in a consecutive order between March/1998 and November/1999. Of these patients, $119(90.8 \%)$ were males and $12(9.2 \%)$ were females, with an average age of $44.3 \pm 10.8$ years. They ingested a mean daily amount of $299 \pm 146 \mathrm{~g}$ of ethanol for a mean period of $23.5 \pm 10.5$ years. After informed consent from each patient, serum antibodies against HIV (HIV-1/HIV-2) were determined by an enzyme-linked immunosorbent assay (ELISA) utilizing the Vironostika ${ }^{\mathrm{R}}$ HIV UniForm II plus O kit (Organon Teknika BV, Boxtel, Netherlands) and the Abbott AXSYM ${ }^{\mathrm{R}}$ System (Recombinant Antigens and Synthetic Peptides, Abbott GmbH Diagnostika, WiesbadenDelkenheim, Germany). When a positive test was obtained, the serology was repeated for confirmation. To enable us to compare the patients from this study to our previous study (Oliveira et al. 1999), we determined the prevalence of serological markers for HBV (anti-HBc) by the ELISA method (Abbott AXSYM ${ }^{\mathrm{R}}$ System, Abbott GmbH Diagnostika, Wiesbaden-Delkenheim, Germany) and HCV (anti-HCV) by ELISA3 (HCV version 3.0, Abbott GmbH Diagnostika, WiesbadenDelkenheim, Germany). Data about the incidence and prevalence of HIV in the city of Uberlândia were provided by the Health Secretary of the city. 


\section{RESULTS}

Of the 131 patients of this study, four (3\%) had a positive HIV test. All of these were males, three of which were injecting drug users (IDU) apart from being sexually promiscuous. They also had come to the emergency room on several occasions due to alcoholism. Two of them had previous history of receiving blood transfusions and one had body tattoos. The fourth patient was sexually promiscuous, reporting unprotected sexual behavior and no history of IDU, blood transfusion or tattoos (Table). Of the four injecting drug user belonging to the group studied, three $(75 \%)$ had positive HIV tests. Among the alcoholics that were not users of injected drugs only one $(0.7 \%)$ had a positive HIV test.

Of the patients that were HIV negative, four had body tattoos, 16 had received blood transfusions, 34 had undergone surgical procedures and one was an IDU. All patients denied homosexual behavior but most of them were sexually promiscuous and frequently had unprotected sexual encounters.

The first case of acquired immunodeficiency syndrome (Aids) in Uberlândia was diagnosed in 1985 and the incidence of the disease is now approximately 100 cases/year (1998 and 1999). There are now 300 Aids patients under treatment and since it is estimated that for each case of Aids there are between 50 and 100 asymptomatic HIV carriers; there would be an estimated prevalence of HIV infection of $15,000(3.1 \%)$ to $30,000(6.2 \%)$ people in Uberlândia's population of 480,000 inhabitants.

Serology for HBV (anti-HBc) and HCV (antiHCV) in these patients was positive in $26.4 \%$ and $4.2 \%$, respectively. Of the four HIV-positive patients, one was also anti-HCV positive and another was positive for both anti-HBc and anti$\mathrm{HCV}$. Both patients were IDU.

\section{TABLE}

Human immunodeficiency virus infection (HIV) in four alcoholic individuals reporting different risk factors of HIV exposure

\begin{tabular}{lllll}
\hline & 1 & 2 & 3 & 4 \\
\hline Injected drug use & + & + & + & - \\
Multiple sexual partners & + & + & + & + \\
Unprotected sexual behavior & + & + & + & + \\
Tattoos & + & - & - & - \\
Blood transfusion & + & - & + & - \\
\hline
\end{tabular}

\section{DISCUSSION}

The high prevalence of serological markers for HBV (26.4\%) and HCV (4.2\%) found in this study was similar to that described in our previous study, which was of $28.3 \%$ and $3.8 \%$, respectively, whereas the prevalence of those markers in blood donors is of $4 \%$ and $0.4 \%$, respectively (Oliveira et al. 1999). Regarding HIV infection, we found four seropositive patients reporting sexual promiscuousness and unsafe sexual encounters and three of them (75\%) were IDU.

Due to the relatively high incidence of HIV infection in our community, estimated between $3.1 \%$ to $6.2 \%$ of the population, the prevalence of HIV infection among non-IDU alcoholics was low $(0.7 \%)$. Our results are similar to those found in patients with alcoholic hepatic cirrhosis, where a high risk for HBV (32\%) was observed but not for HIV (0\%) infection (Buffet et al. 1988). Although we had only four IDU in this study, three of them $(75 \%)$ were HIV positive, which is in accordance with data reported by Schleifer et al. (1989), with a prevalence of $4.5 \%$ of HIV-1 infection among alcoholics who denied a history of IDU and a prevalence of $48.1 \%$ among alcoholics that were IDU. This suggests that the two subgroups are different and have distinct risks for HIV infection. Also, Jacobson et al. (1992) found 13\% of seropositivity for HIV and 40\% for hepatitis B in 143 alcoholics, where the most important risk factors for HIV infection were use of injected drugs or sexual contact with an IDU.

One could argue that the average age of the patients in this study ( $44.3 \pm 10.8$ years) is relatively high, since younger people are more predisposed to acquire HIV infection. However, in a study done in heterosexual alcoholics, like in this study, $5 \%$ of HIV seropositivity was found, with no differences in relation to age (Avins et al. 1994).

Our results allow us to conclude that, in the group studied, alcoholism per se did not represent a risk factor for HIV infection, contrary to alcoholism associated with IDU. Nevertheless, as HIV has similar transmission routes to $\mathrm{HBV}$ and $\mathrm{HCV}$, and as the infection by the latter viruses is highly prevalent among alcoholics, an increase in the incidence of HIV infection among these patients may be just a matter of time, since HIV has appeared only recently in the general population. Thus, we consider the treatment of alcoholism to be of the utmost importance for the prevention of HIV infection in alcoholics, since it has been shown that alcoholics that stop drinking decrease their unsafe behavior, i.e., the risk factors are associated with active alcoholism (Scheidt 1999). We also consider the education of these individuals about 
preventive measures to be very important in preventing HIV infection.

\section{REFERENCES}

Avins AL, Woods WJ, Lindan CP, Hudes ES, Clark W, Hulley SB 1994. HIV infection and risk behaviors among heterosexuals in alcohol treatment programs. JAMA 271: 515-518.

Basile A, Vitale G, Macor C 1981. Hepatitis B virus infection in alcoholics cirrhosis. Brit Med J 282: 1705.

Befrits R, Hedman M, Blomquist L, Allander T, Grillner L, Kinnman N, Rubio C, Hultcrantz R 1995. Chronic hepatitis $\mathrm{C}$ in alcoholic patients: prevalence, genotypes, and correlation to liver disease. Scand J Gastroenterol 30: 1113-1118.

Boscarino JA, Avins AL, Woods WJ, Lindan CP, Hudes ES, Clark W 1995. Alcohol-related risk factors associated with HIV infection among patients entering alcoholism treatment: implications for prevention. $J$ Stud Alcohol 56: 642-653.

Bréchot C, Nalpas B, Couroucé AM, Duhamel G, Callard P, Carnot F, Tiollais P, Berthelot P 1982. Evidence that hepatitis $\mathrm{B}$ virus has a role in liver-cell carcinoma in alcoholic liver disease. New Engl J Med 306: 13841387.

Buffet C, Champsaur H, German-Fattal M, Lambert T, Briantais MJ, Etienne JP 1988. Alcoholic cirrhosis patients and HIV infection. Dig Dis Sci 33: 10491050.

Caldwell SH, Jeffers LJ, Ditomaso A, Millar A, Clark RM, Rabassa A, Reddy KR, De Medina M, Schiff ER 1991. Antibody to hepatitis $C$ is common among patients with alcoholic liver disease with and without risk factors. Am J Gastroenterol 86: 1219-1223.

Fitterling JM, Matens PB, Scotti JR, Allen Jr JS 1993. AIDS risk behaviors and knowledge among heterosexual alcoholics and non-injecting drug users. Addiction 88: 1257-1265.

Gonzáles Quintela A, Alende R, Aguilera A, Tomé S,
Gude F, Pérez Becerra E, Torre A, Martínez Vázquez JM, Barrio E 1995. Anticuerpos frente al virus C de la hepatitis en alcohólicos activos. Rev Clín Esp 195: 367-372.

Halimi C, Dény P, Gotheil C, Trinchet JC, Mal F, Scavizzi M, Beaugrand M 1991. Pathogenesis of liver cirrhosis in alcoholic patients: histological evidence for hepatitis C virus responsibility. Liver 11: 329-333.

Hislop WS, Follett EAC, Bouchier IAD, MacSween RNM 1981. Serological markers of hepatitis B in patients with alcoholic liver disease: a multi-centre survey. J Clin Pathol 34: 1017-1019

Jacobson JM, Worner TM, Sacks HS, Lieber CS 1992. Human immunodeficiency virus and hepatitis B virus infections in a New York City alcoholic population. J Stud Alcohol 53: 76-79.

Laskus T, Radkowski M, Lupa E, Horban A, Cianciara J, Slusarczyk J 1992. Prevalence of markers of hepatitis viruses in out-patient alcoholics. J Hepatol 15: 174-178.

Naito K, Tsuji T, Nozaki H, Nagashima H 1977. High prevalence of hepatitis B virus infection among heavy alcohol drinkers in Japan. Microbiol Immunol 21: 735-738.

Oliveira LCM, Buso AG, Rodrigues de Oliveira AT, Arantes CA, Borges LV, Valente SRG 1999. Prevalence of hepatitis B and hepatitis $C$ markers in alcoholics with and without clinically evident hepatic cirrhosis. Rev Inst Med Trop S Paulo 41: 69-73.

Scheidt DM 1999. HIV risk behavior among alcoholic inpatients before and after treatment. Addict Behav 24: 725-730.

Schleifer SJ, Keller SE, Lombardo JM, Franklin JE, LaFarge S, Miller SI 1989. HIV-1 antibody reactivity in inner-city alcoholics. JAMA 262: 2680-2681.

Shillington AM, Cottler LB, Compton WM3 $3^{\text {rd }}$, Spitznagel EL 1995. Is there a relationship between "heavy drinking" and HIV high risk sexual behaviors among general population subjects? Int J Addict 30: 1453-1478. 